\title{
Penicillinase producing Neisseria gonorrhoeae in Zurich, Switzerland
}

\author{
ALFRED R EICHMANN* AND JEAN-CLAUDE PIFFARETTI† \\ From the *Department of Dermatology and Venereology, University Hospital, Zurich, and $\uparrow$ The \\ Cantonal Institute of Bacteriology, Lugano, Switzerland
}

SUMMARY Of 1031 consecutive isolates of Neisseria gonorrhoeae examined before 31 July 1982 , 30 strains showed $\beta$-lactamase activity. All the penicillinase producing $N$ gonorrhoeae (PPNG) strains were imported, 23 of them from South East Asia. One PPNG strain was identified as coming from Antigua and one from Chile, the first PPNG strains to be reported from these two countries. In 28 strains, the minimum inhibitory concentration (MIC) of penicillin was $\geqslant 4 \cdot 0 \mathrm{mg} / \mathrm{l}$, and 15 strains were insensitive to tetracycline (MIC $\geqslant 2.0 \mathrm{mg} / \mathrm{l}$ ). Four strains were less sensitive to spectinomycin $(\mathrm{MIC}=30 \mathrm{mg} / \mathrm{l})$, while the remaining 26 were highly sensitive to this antibiotic. The African plasmid was found in only one strain (that originating from Antigua), and all other PPNG strains contained the Asian plasmid. Twenty PPNG strains contained the resistance plasmid together with the transfer plasmid. Auxotype determination showed that 18 PPNG strains were prototrophic whereas 11 were proline requiring.

\section{Introduction}

Penicillinase producing Neisseria gonorrhoeae (PPNG) strains were first isolated in Switzerland in 1978 by Novak in Berne; ${ }^{1}$ they originated from Thailand. A further strain of Philippine origin was encountered by Sitavanc et al in 1979 in Geneva. ${ }^{2}$ The first systematic study to be performed in Switzerland began in 1980 in the greater area of Zurich which, with its $\mathbf{4 0 0 0 0 0}$ residents, is the largest city in Switzerland. It is also a busy international banking centre, a popular tourist centre, and an important transfer point because of its airport. A preliminary study showed that during a period of 15 months, 10 of $601(1 \cdot 7 \%)$ gonococcal isolates were PPNG strains, ${ }^{3}$ all of which were imported. By August 1982, 44 PPNG strains had been isolated in Switzerland, ${ }^{4}$ most (30 strains) having been isolated in Zurich. We discuss the epidemiological and microbiological aspects (including the plasmid content) of 29 of these strains.

Address for reprints: Dr A R Eichmann, Department of Dermatology and Venereology, University Hospital of Zurich, Gloriastrasse $31 \mathrm{Ch}-8091$, Zurich, Switzerland

Accepted for publication 13 September 1983

\section{Materials and methods}

ISOLATION OF GONOCOCCAL STRAINS

Strains were obtained from the clinic for skin and venereal diseases and the gynecological clinic of the University Hospital, or isolated from clinical specimens sent by the city medical clinics and by various established doctors in the Zurich region. Samples were cultured on modified Thayer-Martin medium for 48 hours at $37^{\circ} \mathrm{C}$ in $5 \%$ carbon dioxide, and gonococci were identified by morphological (Gram stain) and biochemical (oxidase and carbohydrate degradation) tests. All isolates were tested for $\beta$-lactamase activity by the chromogenic cephalosporin test. ${ }^{5}$

TESTING FOR SENSITIVITY TO ANTIBIOTICS Minimal inhibitory concentrations (MICs) of penicillin, tetracycline, and spectinomycin were measured by the agar dilution method. ${ }^{5}$ Chocolate agar (Go Agar Base Oxoid 4\%, haemolysed human blood 7\%, and Isovitalex 1\%) containing twofold dilutions of the drug to be tested was inoculated with $N$ gonorrhoeae suspensions using a Steers multipoint inoculator. The gonococcal suspensions were dissolved in trypticase soy broth, ${ }^{5}$ and standardised 
at $10^{8}$ colony forming units $(\mathrm{cfu}) / \mathrm{l}$ or at a McFarland barium sulphate standard No $0 \cdot 5$. This suspension was diluted with trypticase soy broth in a ratio of 1:20. After incubation for 24 hours at $37^{\circ} \mathrm{C}$, the MIC was identified as the lowest concentration at which there was no growth visible to the naked eye. Three reference strains (III, V, and VII) of $N$ gonorrhoeae from the WHO Reference Laboratory for Neisseria Diagnostic in Copenhagen were included as controls.

The range of concentrations of the antibiotics tested was $16 \cdot 0-0 \cdot 007 \mathrm{mg} / \mathrm{l}$ benzyl penicillin $\mathrm{G}$, $4 \cdot 0-0 \cdot 25 \mathrm{mg} / 1$ tetracycline hydrochloride, and $120-3 \cdot 75 \mathrm{mg} / \mathrm{l}$ spectinomycin hydrochloride.

\section{PLASMID DETERMINATION}

Plasmid deoxyribonucleic acid (DNA) was prepared by the method of Birnboim and Doly ${ }^{7}$ and analysed by electrophoresis through $0.8 \%$ agarose at a constant voltage of $2 \mathrm{~V} / \mathrm{cm}$ for 15 hours with a continuous recirculation of the running buffer $(20 \mathrm{mmol} / \mathrm{l}$ trometamol (TRIS)-hydrochloric acid, $10 \mathrm{mmol} / \mathrm{l}$ sodium acetate, $0.5 \mathrm{mmol} / 1$ ethylenediaminetetraacetic acid (EDTA), pH 8.0). Plasmid molecular weights were determined by coelectrophoresis with plasmids of known size.

\section{AUXOTYPE ANALYSIS}

Nutritional growth requirements (auxotyping) of PPNG were determined by the method of Catlin. ${ }^{89}$ The NEDA (neisseria defined agar) basic medium was used omitting one or several of the following amino acids; proline, arginine, ornithine, uracil, hypoxanthine, methionine, or leucine. The gonococcal strains were subcultivated on modified Thayer-Martin medium for 14 hours at $37^{\circ} \mathrm{C}$ in $5 \%$ carbon dioxide. One platinum loopful of bacteria was suspended in $3 \mathrm{ml}$ buffered salt solution (following Catlin), ${ }^{9}$ adjusted to a concentration of $10^{11} \mathrm{cfu} / \mathrm{l}$, and inoculated using a Steers multipoint inoculator. The results were read after incubation for 48 hours, and were considered positive only when colonies were seen with the naked eye.

\section{Results}

Of the 1031 isolates of $N$ gonorrhoeae, 30 were PPNG strains. Four were found in women (cervix) and 26 in men (urethra). All 26 men had urethritis. Two of the women had cervicitis, one had salpingitis, and the other was asymptomatic. Of the 30 patients, 28 were Swiss residents and two were tourists. Table I shows the origin of the PPNG strains isolated in the Zurich area. More than three quarters were acquired in South East Asia, two in Africa and three in Central or South America. Both the strains acquired in Zurich were from partners infected abroad (Philippines and Ghana).
TABLE 1 Geographic origin of the 30 PPNG strains isolated in Zurich (1980-2)

\begin{tabular}{lc}
\hline Infection in & $\begin{array}{l}\text { No of } \\
\text { strains }\end{array}$ \\
\hline South East Asia: & \\
Philippines & 16 \\
Thailand & 6 \\
Singapore & 1 \\
Africa: & 1 \\
Nigeria & 1 \\
Ghana & 1 \\
America: & 1 \\
Antigua & 1 \\
Brazil & 1 \\
Chile & $2 *$ \\
Switzerland: & 2 .rich
\end{tabular}

*Partners infected abroad (Philippines and Ghana).

Of the 30 PPNG strains isolated, 29 were further characterised, and their antibiotic sensitivities are shown in table II. Most of the PPNG had an MIC of penicillin $G$ of $\geqslant 4 \mathrm{mg} / \mathrm{l}$, were rather insensitive to tetracycline (MIC $\geqslant 1 \mathrm{mg} / \mathrm{l}$ ), and highly sensitive to spectinomycin (MIC $\leqslant 15 \mathrm{mg} / \mathrm{l}$ ), with the exception of four strains which were moderately sensitive to this drug (MIC $=30 \mathrm{mg} / \mathrm{l})$.

TABLE II Minimum inhibitory concentrations $(\mathrm{mg} / \mathrm{l})$ of different antibiotics for 29 PPNG strains isolated in Zurich (1980-2)

No of PPNG strains inhibited by:

\begin{tabular}{llllllllllllllll}
\hline $\begin{array}{l}\text { Penicillin } G \\
(m g / l)\end{array}$ & \multicolumn{4}{l}{$\begin{array}{l}\text { Tetracycline } \\
(m g / l)\end{array}$} & & & \multicolumn{4}{l}{$\begin{array}{l}\text { Spectinomycin } \\
(m g / l)\end{array}$} \\
\hline 2.0 & 4.0 & 8.0 & 16.0 & 0.25 & 0.5 & 1.0 & 2.0 & 4.0 & 7.5 & 15.0 & 30.0 \\
\hline 1 & 12 & 6 & 10 & 1 & 2 & 11 & 7 & 8 & 7 & 18 & 4 \\
\hline
\end{tabular}

Table III shows results of the plasmid determinations. The African resistance plasmid (3.2 Megadaltons (Mdal)) was present only in the strain origin-

TABLE III Plasmid content of 29 PPNG strains isolated in Zurich (1980-2)

\begin{tabular}{|c|c|c|c|c|c|}
\hline \multirow{2}{*}{$\begin{array}{l}\text { Geographic } \\
\text { origin }\end{array}$} & \multirow{2}{*}{$\begin{array}{l}\text { No of } \\
\text { strains }\end{array}$} & \multicolumn{4}{|c|}{ Size of plasmid (Mdal) } \\
\hline & & $2 \cdot 6$ & $3 \cdot 2$ & $4 \cdot 4$ & $24 \cdot 5$ \\
\hline Philippines & 12 & + & & + & + \\
\hline Philippines & 4 & + & & + & \\
\hline Thailand & 5 & + & & + & + \\
\hline Thailand & 1 & + & & + & \\
\hline Singapore & 1 & + & & + & + \\
\hline Nigeria & 1 & + & & + & \\
\hline Ghana & 1 & + & & + & \\
\hline Antigua & 1 & + & + & & \\
\hline Brazil & 1 & + & & + & + \\
\hline Chile & 1 & + & & + & + \\
\hline
\end{tabular}

Note: The $2 \cdot 6,3 \cdot 2,4 \cdot 4$, and $24 \cdot 5$ Megadalton plasmids correspond to the cryptic, African resistance, Asian resistance, and transfer plasmids respectively. 1314 
ating from Antigua, the other isolates harbouring the Asian genetic element (4.4 Mdal). The auxotype analysis showed that 18 strains were prototrophic and 11 were proline requiring. Of the 23 strains acquired in South East Asia, 15 were prototrophic and eight were proline requiring. The two strains acquired in Africa and the strain from Brazil were proline requiring, while the strains from Chile and Antigua were prototrophic.

\section{Discussion}

More than three quarters of the PPNG strains isolated in Zurich were imported from South East Asia. This confirms the fact that most PPNG strains have originated in South East Asian countries. From an epidemiological point of view it is also important that PPNG strains have been encountered for the first time from Antigua and Chile. All the PPNG strains isolated in the Zurich area originated from abroad, either directly (infection in a foreign country) or indirectly (infection by a partner infected abroad). This supports findings which show that in Switzerland there is at present no endemic PPNG problem. ${ }^{4}$ It is not surprising that most of the PPNG strains isolated were of Asian origin if we consider that South East Asia is a frequent travel destination for Swiss tourists, especially men. ${ }^{10}$

The number of PPNG infections in the Zurich area is probably higher than our research showed. In Switzerland, in private medical practice where gonorrhoea is diagnosed, spectinomycin is often prescribed without laboratory confirmation of infection. According to information from the manufacturers, 13500 ampcoules of spectinomycin were sold in 1980 in Switzerland. It is therefore probable that an unknown number of PPNG strains were treated without identification. The MIC determination assays showed a limited susceptibility to tetracycline, which is typical of Asian PPNG strains. ${ }^{11}$ Out of the 22 South East Asian strains, only one was sensitive to this drug (MIC $\leqslant 0.5 \mathrm{mg} / \mathrm{l})$; seven strains were resistant $(M I C \geqslant 4.0 \mathrm{mg} / \mathrm{l})$ and 14 were less sensitive to it. The sensitivity of all our isolates to spectinomycin was uniformly good (MIC $\leqslant 30 \mathrm{mg} / \mathrm{l})$.

Plasmid determination showed that most of the resistance plasmids were, as expected, of the Asian type (28 out of 29); an interesting observation was that the strain from Antigua harboured a resistance plasmid of the African type (3.2 Mdal) whereas that from Chile contained the Asian type (4.4 Mdal). Another interesting observation was that the PPNG strain from Nigeria was found to harbour an Asian plasmid. This confirms recent reports of PPNG strains from Africa. ${ }^{12}$ At present most of the PPNG resistance plasmids encountered in the Zurich area, as well as elsewhere in the world, are of the Asian type. There may be two reasons for this: a) since their appearance, the Asian plasmids have often been found together with the transfer plasmid ( 22 out of 28 in this report, see table III), which increases their chance of spreading. (This is generally not the case for the African resistance plasmids, which have only recently been found with transfer plasmids ${ }^{13}$ ); b) Europeans and Americans travel more often to South East Asia than to Africa and are therefore obviously more likely to be infected with Asian strains of PPNG.

The 29 PPNG strains we analysed were either prototrophic or proline requiring, which agrees with data published recently by several authors showing that all their PPNG strains isolated in the United States and in South East Asia belonged to these two auxotypes. ${ }^{14} 15$

In conclusion, we emphasise that PPNG strains isolated so far in the Zurich area and elsewhere in Switzerland originated from abroad. The fact that PPNG infections are continually brought into Switzerland should alert doctors to the nature of gonococcal resistance to penicillin in this country.

This paper is dedicated to Professor A Luger for his 65th birthday. We thank Mrs Inga Lind for her friendly cooperation and expert advice. Part of this work was supported by a grant (3.769.80) from the Swiss National Science Foundation.

\section{References}

1. Novak A. Empfindlichkeit der Gonokokken gegen Penicillin G im Kanton Bern in den Jahren 1972-1977. Schweiz Med Wochenschr 1978; 108: 98-101.

2. Sitavanc M, Heitz M, Pitton JS. Apparation à Genève d'une souche de gonocoques productrice de B-lactamase. Med Hyg Genève 1979; 37:3877-80.

3. Eichmann F, Stieger A, Schwartz K, Konzelmann $M$. $\beta$-Lactamase produzierende Gonokokken in der Region Zürich. Epidemiologie und Empfindlichkeit gegenüber verschiedenen Antibiotika. Schweiz Med Wochenschr 1982; 112:713-8.

4. Arini A, Peduzzi R, Piffaretti JC. Epidemiologie de $\mathbf{N}$ gonorrhoeae isolée en Suisse: Sensibilité aux antibiotiques et auxotypie. Schweiz Med Wochenschr 1983;113:462-70.

5. Thornsberry C, Gerlach EH, Sherris JC. New developments in antimicrobial agent susceptibility testing. In: Sherris JD ed. Cumitech 6. Washington DC: American Society for Microbiology, 1977.

6. Reyn A, Thornsberry C, Wilkinson AE. Susceptibility testing of Neisseria gonorrhoeae to antimicrobial agents. Recommended methods and use of reference strains. WHO/VDT/RES/GON/80. 1980;129:1-16.

7. Birnboim HC, Doly J. A rapid alkaline extraction procedure for screening recombinant plasmid DNA, Nucleic Acids Res 1979; 7: 1513-23.

8. Carifo K, Catlin BW. Neisseria gonorrhoeae auxotyping: Differentation of clinical isolates based on growth responses on chemically defined media. Applied Microbiology 1973;26: 223-30.

9. Catlin BW. Nutritional profiles of Neisseria gonorrhoeae, Neisseria meningitidis, and Neisseria lactamica in chemically defined media and the use of growth requirements of gonococcal typing. $J$ Infect Dis 1973; 128: 178-94. 
10. Eichmann A. Gonorrhoe in Zürich: Auswertung einer Stichprobe, antibiotische Empfindlichkeit der Erreger, Penicillinase produzierende Stämme und Auxotypisierung. Zürich: Habilitationsschrift. Medizinische fakultăt Universităt Zürich, 1984.

11. Jaffe HW, Biddle JW, Johnson SR, Wiesner PJ. Infections due to penicillinase producing Neisseria gonorrhoeae in the United States; 1976-1980. J Infect Dis 1981;144:191-7.

12. Odugbemi TO, Brown ST, Biddle J, et al. Plasmid profile, serogrouping, and auxotyping of $N$ gonorrhoeae isolates from Africa. Br J Vener Dis 1983;59:41-43.
13. Van Embden JDA, Van Klingeren B, Dessens-Kroon $\mathbf{M}$, Van Wijngaarden LJ. Emergence in the Netherlands of penicillinase-producing gonococci carrying "Africa" plasmid in combination with transfer plasmid. Lancet 1981; i: 938 .

14. Handsfield HH, Sandstrom EG, Knapp JS, et al. Epidemiology of penicillinase-producing Neisseria gonorrhoeae infections. N Engl J Med 1982;306:950-4.

15. Bygdeman S, Kallings I, Danielsson D. Serogrouping and auxotyping for epidemiological study of $\beta$-lactamase producing $N$ gonorrhoeae strains isolated in Sweden. Acta Derm Venereol (Stockh) 1981;61:329-34. 